DOI: 10.46340/ephd.2021.7.3.14

\author{
Anna Seliverstova \\ ORCID ID: https://orcid.org/0000-0001-892 \\ South Ukrainian National Pedagogical University named after K.D. Ushynsky, \\ Odesa, Ukraine
}

\title{
THEORETICAL BASES FOR THE STUDY \\ OF THE CHAOTIZATION \\ OF PSYCHO-DIMENTIONALITY OF SOCIETY
}

\author{
Ганна Селіверстова \\ Південноукраїнський національний педагогічний університет ім. К.Д. Ушинського, \\ м. Одеса, Україна
}

\section{ТЕОРЕТИЧНІ ЗАСАДИ ДОСЛІДЖЕННЯ ХАОТИЗАЦІЇ ПСИХОМІРНОСТІ СОЦІУМУ}

The aim of the article is to study the chaos and chaotic processes of society, which today are under the influence of global political, economic, environmental, socio-cultural turmoils and crises that encompassed the world in the first third of the New Millennium, become the subject of much interdisciplinary research.

In this regard, the article presented the main philosophical meanings and senses contain ed in the concept of "chaos" in the mythological, religious and philosophical thought of the period of Antiquity and the Ancient World. In addition, the paper examines the evolution of interpretations and meanings of chaos, which lasted from ancient philosophical thought to modern postmodern philosophy.

It was the first time a comprehensive study of the phenomenon of social chaos and chaotic processes of social reality, based on post-classical methodology, represented by synergetic and psychosynergetic studies of representatives of the philosophical and scientific Ukrainian synergetic school (I.S. Dobronravova, I.V. Yershova-Babenko, L D. Bevzenko, I.A. Donikova, and others). The idea of social chaos as a necessary element of the development of the social system was also developed, which leads to the destruction of the old structures of the social order and contributes to the formation of new ones.

Thus, social systems from the standpoint of synergetics and psychosynergetics are open complex, self-organizing environments. The study concluded that the goals and objectives of research used in modern environmental philosophy (E.Moren, N. Talib, O.M. Knyazeva, etc.), which proposes the idea of human ecology and its psyche, social behavior and actions, and psychosynergetics, which is also focused on preserving the ecology of the human psyche, which is under the influence of chaotic mental and social realities, offering certain scientific techniques and developments for self-regulation.

A new concept "chaotization of the psycho-dimensionality of society" has been put into scientific circulation, which reveals the role and influence of the social subject and his psyche on the processes of chaotic social reality in periods of social bifurcations (social conflicts, crises, revolutions). The meaning of the concept of "psycho-dimensionality of social reality" was clarified, which shows the importance of the psychological component of personality in its social dimension (communication, behavior, etc.). Thus, the growing role of society as a psycho-dimensional system/environment self-organizing in social chaos was revealed.

Keywords: chaos, chaotization, psychosynergetics, psycho-dimensionality, self-organization society, philosophy.

Постановка проблеми. Актуальність теми хаосу в сучасному соціально-гуманітарному знанні не викликає ніяких сумнівів, настільки очевидними $є$ ті виклики, кризи і глобальні проблеми, з якими стикається сьогодні весь цивілізований світ. Але якщо в природничо-науковому знанні темі хаосу 
присвячені численні дослідження $\mathrm{i}$ роботи, що подані утаких фундаментальних науках як математика, фізика, хімія, біологія тощо. То у соціально-гуманітарному знанні, в першу чергу в філософії та соціальній філософії, ще відчувається потреба у повному і всебічному вивченні феномена хаосу, в розвитку і удосконаленні теоретико-концептуальних моделей інтерпретації соціального хаосу і взаємодії з ним у різних сферах соціального, політичного, економічного і культурного життя. У соціально-філософському пізнанні актуальність досліджень хаосу набуває значущості в зв'язку з проблемою зміни і розвитку соціальних систем, які самоорганізуються, що розширює поле досліджень соціальної нестабільності і невизначеності, пропонує нові моделі соціального управління і прогнозування на підставі синергетичної методології.

Мета дослідження. Важливість осмислення феномена хаосу і хаотизації соціальних процесів у сучасній соціально-філософській думці та їх недостатнє висвітлення зумовили постановку наукового завдання, а саме його мету - проаналізувати феномен соціального хаосу на підставі психосинергетичного підходу. Цей сучасний постнекласичний підхід розкриває можливості психосинергетики як нової дисципліни, сформованої на стику синергетики і психології, що дає нові перспективи для дослідження соціальних систем (особистість і суспільство) як психомірних систем/середовищ, що самоорганізуються. Також його застосування дозволяє поширити психосинергетичні методи дослідження на сферу соціальної філософії для вирішення проблем буття людини, екології їі життєдіяльності у внутрішньо особистісному і соціальному вимірі, актуалізуючи питання iї самореалізації, саморозвитку і самоорганізації.

Виклад основного матеріалу. Для обгрунтування теоретичних засад хаотизації соціуму, перш за все, слід визначити що таке хаос, які процеси та явища $є$ хаотичними і з чого починається процес хаотизації. Основні смисли хаосу як явища та поняття були розкриті у філософському знанні, починаючи 3 періоду античної філософської думки і закінчуючи сучасними постмодернистськими концепціями, пов'язаними як з самим поняттям хаосу, так із похідним від нього поняттям «хаосмос» ${ }^{1}$. Крім того, існують також міфологічні і релігійні витоки формування поняття хаосу, оскільки на них спиралась антична філософська думка, по-різному їх інтерпретуючи. У поета Гесіода, який першим ввів це поняття, хаос трактується як первинна безодня, перший стан існування світу, який немає впорядкування i визначеності ${ }^{2}$. Виходячи 3 порівняння гесіодовської думки i інших міфологічних тверджень про походження світу, які присутні у китайській, давньоєгипетській, вавілоно-шумерській, фінікійській та інших міфологіях, можна побачити деякі спільні моменти ${ }^{3}$. А саме поняття хаосу завжди пов'язано 3 утворення світу, тобто воно уявляється як первісний стан речей до появи визначеності і оформленності світу як космосу. Навколишній світ (космос) утворюється або в результаті космічної боротьби сил хаосу 3 іншими силами, або переходу від хаосу до космосу на підставі дій різноманітних богів.

Філософські тлумачення хаосу 3'являються у класичній філософській думці- Платона i Арістотеля, які визначають його по-різному, а також у Зенона, засновника стоїцизму, який інтерпретує хаос як «воду», або «вологу», повертаючись до деяких інтерпретацій хаосу, що були присутні у орфіків і ранніх філософів ${ }^{4}$. Наступні інтерпретації хаосу у період пізньої античності або продовжують традицію Арістотеля і визначають хаос як щось, необмежене: простір (Секст Емпірик), або час (Марк Аврелій). Інші за основу беруть Зенона і певною мірою Платона, для яких хаосце життєутворююча матерія, що підживлює існування світу5.

Таким чином, антична філософська думка повністю відходить від будь-яких міфологічних образів Хаосу (як наприклад, у Гесіода «похмура, темна безодня») і тлумачить його посилаючись на певні філософські аргументи, які вважають хаос необхідною складовою світу або з точки зору простору (порожнеча, що вміщує речі світу), або як елемент, речовина, що дає життя для космосу і утворення речей ${ }^{6}$.

\footnotetext{
${ }^{1}$ Грицанов, А. (2007). Хаосмос. Постмодернизм. Новейший философский словарь. Минск: Современный литератор, 815

${ }^{2}$ Рожанский, И.Д. (1972). Анаксагор. У истоков античной науки. Москва: Мысль, 43.

${ }^{3}$ Єршова-Бабенко, І. В., Селіверстова, Г. (2021). «Зв’язок часів» крізь призму поняття «хаос»

в давньокитайській міфології і соціальній філософії XXI ст. Norwegian Journal of development of the International

Science, 64, 53-54.

4 Лебедев, А. В. (1989). Фрагменты ранних греческих философов. Москва: Наука, 1, 48.

${ }^{5}$ Токарев, С. А. (ред.) (1980). Хаос. Мифы народов мира: Энциклопедия. Электронное издание. Москва:

Советская Энциклопедия, 2, 580.

${ }^{6}$ Селіверстова, Г.С. (2021). Хаос як предмет соціальної філософії: дисертація на здобуття наукового ступеня кандидата філософських наук. Одеса: ППНУ ім.К.Д. Ушинського, 30.
} 
Найбільш актуальним філософським концептом хаос стає у сучасній філософській думціу філософії постмодернізму, в якій утворюється допоміжний концепт «хаосмос», що поєднує поняття хаосу i космосу на противагу класичній філософії, яка їх протиставляла. Відштовхуючись від розуміння хаосу як безладу і невизначеності, філософи-постмодерністи між тим бачать його як нескінчений «резервуар можливостей», тобто хаос інтерпретується ними як творча потенційна сила, що здатна руйнувати усталені структури (смисли) і утворювати нові (структури) смисли. Отже, хаос $\epsilon$ інструментом оновлення світу, символом можливості, або навіть необхідності запровадження нового порядку. Тому саме у постмодернізмі виникає концепт «хаосмос», що поєднує обидві інтенції - одночасного руйнування і побудови нового. Тому що хаос надихає на творчість, стимулює розвиток, дає місце для випадковості й невизначеності.

Поза тим, сучасні наукові теорії у математиці, фізиці, біології та в інших природничих науках певним чином вплинули на соціально-гуманітарне знання, започаткувавши вивчення феномену хаосу і процесів хаотизації. Перше за все, це стосується теорії так званого «динамічного» (детермінованого) хаосу, яка почала формуватись у фізиці та математиці у 60-70pp. минулого сторіччя. Першим, хто запропонував математичну модель хаосу на прикладі дослідження атмосферних потоків був американський математик Е. Лоренц, який визначив основну характеристику процесів хаотизації явищ природи: для них $є$ характерною зміна початкових умов під впливом незначних факторів (впливів). Він також сформулював так звану метафору «метелика», яка демонструє зв'язок між слабким впливом (незначною подією) на рух системи і їі відхиленим від початкових умов (вагомими наслідками), яка набула широкого розповсюдження у соціально-гуманітарних дослідженнях, і навіть у мистецтві ${ }^{1}$. Математичною моделлю хаотичних процесів стали «дивні атрактори», які утворювали певні геометричні структури (фрактали), які мали самоподібну форму. Дослідженню фракталів присвячена фрактальна геометрія, яка була запропонована французським математиком Б. Мальденбродом².

3 іншого боку, у хімії на прикладі реакції Белоусова-Жаботинського, «хімічного годинника» почали вивчати процеси самоорганізації (коливань), які виникали виключно при особливому режимі функціонування системи - хаотичному. У фізиці (теорії динамічних систем) було встановлено, що рух динамічних систем при певних умовах виходить за рамки класичних уявлень і стає хаотичним, демонструючи складний порядок. Ці наукові факти дозволили I.P. Пригожину створити теорію «дисипативних структур», тобто структур які утворюються в будь-якій системі при входження іiі у хаотичний режим ${ }^{3}$.

Таким чином, розвиток наукових досліджень хаосу у природознавстві у другій половині XX ст. мав суттєвий внесок у розвиток наукових теорії хаосу (теорії динамічного хаосу), а також створення різних математичних моделей хаотизації будь-яких природних явищ. Однак різні галузеві дослідження хаосу спирались на специфіку тих чи інших природних об'єктів і тому визначення хаосу як цілісного феномену стало можливим тільки у синергетиці Г. Хакена і теорії дисипативних структур I.P. Пригожіна ${ }^{4}$.

Сьогодні вже є очевидним, що синергетика як науково дослідницька програма дозволяє вивчати неорганізовані, хаотичні аспекти різних видів реальностей, крім природної, а саме: соціокультурної, психічної, історичної та інших. Оскільки вона допомагає описувати, спираючись на певний теоретико-методологічний інструментарій, виникнення і формування складних цілісностей, а також фаз переходу складних відкритих систем, що саморозвиваються, від одного стану до іншого. Серед цілей і завдань, що стояли перед синергетикою першорядним було вивчення процесів самоорганізації в складних відкритих системах. Спочатку такі системи були знайдені до серед природних і технічних об'єктів, а зараз мова йде і про соціальні, або, точніше, «антропо-соціо-культурні системи» ${ }^{5}$. У зв'язку

\footnotetext{
${ }^{1}$ Lorenz, E.N. (1972). Predictability: does the flap of a butterfly's wings in Brazil set off a tornado in Texas? 139th Annual Meeting of the American Association for the Advancement of Science (29 Dec 1972), in Essence of Chaos. Appendix 1, 181.

${ }^{2}$ Maldenbrot, B. (1982). The Fractal Geometry of Nature. San Francisco: H. Freeman and Co, 460.

${ }^{3}$ Николис, Г., Пригожин, И. (1979). Самоорганизация в неравновесных системах: от диссипативных структур к упорядоченности через флуктуащии. Москва: Мир, 512.

${ }^{4}$ Хакен, Г. (1980). Синергетика. Москва: Мир, 405.

${ }^{5}$ Астафьева, О. Н., Добронравова, И. С. (2009). Социокультурная синергетика в России и Украине: предметная область, история и перспективы. Постнеклассика: философия, наука, культура: Коллективная монография. Санкт-Петербург: Міръ, 634-635.
} 
3 цим впровадження синергетики в область соціально-гуманітарного знання мало важливе значення, в першу чергу, завдяки iі теоретико-методологічного потенціалу, який виявився корисним для вивчення соціальних явищ і процесів. Але й також у зв'язку з появою і розвитком нового нелінійного мислення, яке засноване на поняттях «самоорганізація», «хаос», «біфуркація», «флуктуація», «атрактор», тощо.

Засновники двох провідних шкіл синергетики I.P. Пригожин і Г. Хакен визнавали необхідність розширення синергетичних досліджень на область соціально-гуманітарних наук. В теперішній час, на початку XXI ст., соціальна / соціокультурна синергетика охоплює широке коло процесів і явищ соціально-культурного життя, до яких відносять: явища самоорганізації і динаміки соціокультурних систем (В.В. Васількова, О.Н. Астаф’ева, Л.Д. Бевзенко, В.С. Капустін, І.М. Предборська і ін.); процеси історичної динаміки і цивілізаційних криз (Н.Н. Мещерякова, Л.Й. Бородкін, А.В. Коротаєв, А.П. Назаретян, А.В. Халаспіс і ін.); процеси історичної динаміки культури (М.С. Каган, В.П. Бранський, А. Свідзинський, І.А. Донікова); явища і процеси соціальної трансформації, управління і самоврядування соціальних систем (В.Л. Романов, Д.С. Чернавський, М.С. Дмитрієва, Л.Д. Бевзенко та ін.) та інші ${ }^{1}$. Крім того, розширення синергетичних досліджень торкнулося таких галузей знання як психологія, що призвело до формування нового напрямку досліджень психосинергетика - (І.В. Ершова-Бабенко, Д. Козобродова), педагогічна синергетика - у філософії освіти і педагогіці (В. Кремень, Л. Горбунова, В.С. Лутай, Н.В. Кочубей, О.В. Семенова та ін.), когнітологія (М. Нестерова), тощо.

В області соціальної філософії і соціальних наук розвиток синергетичної парадигми грунтується на вивченні співвідношення процесів соціального порядку і хаосу, які є центральними темами в теорії соціальної самоорганізації. Їх з'єднання означає, що в соціальному розвитку того чи іншого суспільства відбувається періодична зміна станів соціального хаосу (дез-організаціі) і соціального порядку (організаціі). Цей циклічний процес може мати різний характер, але для суспільства як відкритої складної системи, що саморозвивається, він буде закономірним.

В українській філософській думці однієй з перших робіт, в яких висвітлювалася синергетика як загальнонаукова дослідницька програма, була робота І.С. Добронравової «Синергетика: становлення нелінійного мислення» ${ }^{2}$. Багато в чому під впливом цієї піонерської роботи в Україні почалося широке застосування синергетичної методології в області соціально-гуманітарного знання. Наукова монографія I.В. Єршової-Бабенко «Методологія дослідження психіки як синергетичного об’єкту» ${ }^{3}$ продемонструвала, що система людської психіки може бути розглянута як нелінійна складна система, що самоорганізується.

Сучасний світ представлений різними типами соціально-культурних систем, які потребують для дослідження нових епістемологічних принципів, нової постнекласичної методології, що орієнтується на нелінійне мислення і бачення процесів розвитку і співіснування соціальних систем. Отже, в сучасному соціально-філософському знанні необхідною стає синергетична методологія, яка дозволяє перехід від традиційного розуміння буття як сталого, вже сформованого і упорядкованого до буття-становлення, до взаємного співіснування нового і старого, до дослідження процесуальності, невизначеності, нестійкості. Тому у науковий лексикон соціального знання входять такі поняття як «соціальний хаос», «соціальний порядок», «соціальна самоорганізація», «соціальні атрактори», «флуктуації», і багато інших. Таким чином, в рамках синергетичного бачення соціальної реальності проблема «соціального хаосу» находить своє вираження і осмислення ${ }^{4}$.

Незважаючи на те, що проблема соціального хаосу і порядку не є зовсім новою у соціальнофілософській думці, слід зазначати, що вона тривалий час виглядала як проблема подолання соціального хаосу і затвердження соціального порядку. Англійський філософ Т. Гоббс запропонував модель, яка стала класичною і розвивалась досить довгий час у європейській соціально-філософській думці. Він винайшов як позбутися загального хаосу - «війни усіх проти усіх» - на підставі подолання індивідуальної свободи, тобто за рахунок укладення «суспільного договору», в якому держава

\footnotetext{
${ }^{1}$ Селіверстова, Г.С. (2021). Хаос як предмет соціальної філософії: дисертація на здобуття наукового ступеня кандидата філософських наук. Одеса: ППНУ ім.К.Д. Ушинського, 63.

2 Добронравова, И. С. (1990). Синергетика: становление нелинейного мышиления. Киев: Либідь, 149.

${ }^{3}$ Ершова-Бабенко, И. В. (1992). Методология исследования психики как синергетического объекта. Одесса: ОДЭКОМ, 124.

${ }^{4}$ Бевзенко, Л. Д. (2002). Социальная самоорганизация Синергетическая парадигма: возможности социальных интерпретаций. Киев: Институт социологии НАН Украины, 14-15.
} 
утверджується як єдиний керуючий центр, який створює і підтримує соціальний порядок. У філософів XVIII-XIX ст. і класиків соціологічної думки (О. Конт, Е. Дюркгейм, Г. Спенсер, К. Маркс та ін.) гоббсова модель отримала подальший розвиток. Тільки у XX ст. американський соціолог Т. Парсонс, підкреслюючи важливість рішення Гоббса для становлення соціального порядку, тим не менш, вважав його непереконливим, через його недовговічність і можливість повернення до вихідного стану хаосу. Тому робилися спроби її вирішення в рамках посткласичних соціальних теорій П. Бурд’є, А. Гіденса, П. Бергера, Т.Лукмана і інших. Акцент в цих дослідженнях перемістився з пошуку стабільних і незмінних структур на дослідження людських дій, тобто з вивчення нерухомих елементів соціального життя на динамічні аспекти функціонування суспільства. Це призвело до нової інтерпретації самого поняття суспільство - по-перше, воно стало розглядатися з точки зору, такого, в якому постійно відбуваються зміни. По-друге, причини цих змін визначаються як активність соціальних індивідів, які створюють різні конфігурації соціальних структур, що також змінюються у часі. Отже, сучасні соціальні теорії роблять акцент на мінливості, плинності суспільства (З.Бауман), його структуризації (А. Гідденс), і тощо.

Введення синергетики як теорії самоорганізації стало значущим для сучасної соціальної теорії, оскільки в ній пропонується новий погляд на проблему соціального порядку, виходячи з фундаментального положення про єдність і нерозривність порядку і хаосу. Ця нерозривність стає можливою на основі нового розуміння «соціального хаосу»: 1). соціальний хаос відрізняється від безладу, він $є$ порядком, але складним і чутливим $\left.{ }^{1} ; 2\right)$. соціальний хаос - це не будь-яка аморфність, невизначеність. Навпаки, виявляються його найрізноманітніші особливості, специфічні характеристики; 3). соціальний хаос - закономірний, природний стан, типовий для усіх соціальних систем, який періодично наздоганяє систему, і ця неминучість робить його швидше правилом, ніж винятком ${ }^{2}$. Таким чином, сьогодні на підставі синергетичного підходу розглядається роль соціального хаосу як основного елементу необхідного для упорядкування і розвитку соціальної системи (В. Бранський, В.В. Василькова, Л.Д. Бевзенко, та інші). Тобто соціальний хаос виконує функцію «киплячого котла», в якому «дозрівають» нові соціальні структури, що виводять соціальну систему (суспільство) на нову сходинку розвитку. У вітчизняній соціально-філософській думці проблема соціального хаосу вперше досліджувалась у роботі Н. Омельченко ${ }^{3}$, яка вважає, що соціальний хаос $є$ особливим станом складної нелінійної соціальної системи, яке відображає домінування процесів дезорганізації над процесами організації, і тому він $є$ невід'ємною складовою розвитку соціальної системи.

Отже, у сучасній думці під впливом синергетичних ідей вважається, що ідея «соціального становлення〉 $є$ основною для характеристики розвитку людського суспільства в цілому. Вона $\epsilon$ складовою частиною концепції ко-еволюції суспільства і природи, або універсального еволюціонізму, яке в рамках синергетичного світобачення, запропоновали у 1990-х рр. минулого століття М.М. Мойсеєв і С.П. Курдюмов. Останній вважав, що можливо побудувати глобальну теорію «еволюційної динаміки», засадничі положення якої дозволяють зробити глобальне культурноісторичне моделювання, що вивчає певні періоди у розвитку світової історії і культури. Але якщо моделі глобального моделювання за допомогою математичних методів, що впроваджуються у соціально-історичне дослідження ще не є досить поширеними у сучасній науці, то теорія соціальної самоорганізації, яка допомагає дослідити процеси соціальних змін на рівні певного суспільства вже існують і активно розробляються ${ }^{4}$.

Ряд вітчизняних дослідників висунули теоретико-методологічні концепції присвячені проблемі самоорганізації у сучасному суспільстві, пов'язані з вивченням як природи і суті самоорганізації, так і механізмів їі формування. До їх числа відносяться роботи І.С. Добронравової, І.М. Предборської, Л.Д. Бевзенко, І.А. Донікової та інших. У концепції соціальної самоорганізації, запропонованої I. Доніковою, акцент при вивченні явища самоорганізації соціальних систем робиться на культурі як на складної системі, що саморозвивається. В іiї концепції культура постає одним з основних засобів самоорганізації буття людини, який проявляється у соціальній реальності, тому культурогенез

\footnotetext{
1 Ласло, Э. (1995). Век бифуркации: постижение изменяющегося мира. Путь, 1, 4.

2 Бачинин, В.А. (2003). Социология. Харьков: Консум, 540.

${ }^{3}$ Омельченко, Н. (2006). Феномен соціального хаосу: філософський аналіз: автореферат на здобуття наукового ступеня кандидата філософських наук. Запоріжжя: ЗНУ, 20.

${ }^{4}$ Князева, Е. Н., Курдюмов, С. П. (2002). Основания синергетики. Режимы с обострением, самоорганизация, темпомиры. Санкт-Петербург: Алтейя, 414.
} 
$€$ також і антропо-соціогенезом. Культура стає «захисним шаром» людського буття у тому сенсі, що свідомість людини як нелінійна складна система дозволяє направляти людську активність на творчість, дозволяє здійснювати вибір стратегій та інновацій, що перетворюють соціальну дійсність. Тобто, створюючи необхідні умови для реалізації творчої діяльності людини, культура дозволяє нейтралізувати будь-які негативні руйнівні інтенції людської свідомості, тобто перетворити «соціальний хаос» в «культурний космос», сприяючи самореалізації людини ${ }^{1}$. На нашу думку, ці положення про людину як частину єдиного самоорганізованого світу і іiі культуротворчої ролі у процесах соціальної саморганізаціі, що відмічені у концепції І. Донікової, дозволяють не тільки акцентувати увагу на несвідомих, емоційних складових соціальних процесів, але також представити процеси соціальної самоорганізації в повноті людської особистості тобто як єдність ії біопсихічної і соціальної природи.

Тому в рамках теорії соціальної самоорганізації важливий акспект належить багатовимірності людини як соціального суб'єкта, який бере участь процесах самоорганізації, здійснюючи соціальний вибір, що суттєво впливає на розвиток соціальної системи. Отже, вивчення багатовимірності людини дозволяє розширити коло підходів і дисциплин, що можуть бути задіяними для дослідження процесів самоорганізації і хаотизації соціальної реальности. 3 нашої точки зору, важливим здається психологічний аспект, оскільки психосинергетика як дисципліна, що виникла на стику синергетики і психології, дозволює виявити нові грані і питання самоорганізації як на рівні соціальної системи в цілому, та к і на індивідуальному рівня соціального суб'єкта.

Концепція «психомірного середовища/системи» була запропонована у психосинергетиці проф. І.В. Єршовою-Бабенко в результаті досліджень психіки як синергетичного об'екту ${ }^{2}$. У різних наукових роботах вона довела, що особистість людини слід розглядати як складне середовище/систему, що само організується. У різних роботах I. Єршова-Бабенко пропонує нову теоретико-пізнавальну модель психічного, яка дозволяє представити про психіку як гіперсистему, що поєднує свідомість, мозок і власне психічні процеси як нелінійну цілісність ${ }^{3}$. Це означає, що з позицій психосинергетики стає можливим вирішувати багато питань, пов'язаних 3 пізнавальною, творчою, культурною та іншими видами діяльності людини.

В статті пропонується поняття «хаотизація психомірності соціму», яке виражає процеси хаотизації, які починаються на рівні індивіда як соціального суб'єкта, що має незадоволені соціальні очікування, тобто він не може вирішити нагальні питання свого буття в соціумі. Якщо кількість таких суб'єктів і соціальних груп зростає, то утворюється соціальний простір, в якому накопичується соціальна енергія і зростає хаотизація, що потребує певного виходу у різні форми соціального протесту. Ці форми так чи інакше створюють умови для соціальних змін, які можуть проходити поступово або якщо криза наростає у вигляді соціальної «революції», тобто занурення суспільства у соціальний хаос, в якому вирішальну роль вже відіграють самоорганізаційні механізми, за допомогою яких в суспільстві виникає новий порядок.

Таким чином, розвиток соціуму обумовлюється свідомою діяльністю людей, що вказує на «психомірність» як на суттєву характеристику соціальної системи. Саме суб'єкт у ході своєї діяльності будує нові соціальні структури, змінюючи соціальну систему. Однак головним питанням у процесах соціальних змін і соціальних біфуркацій залишається питання як саме соціальний суб'єкт здатен впливати на хід розвитку суспільства, брати участь у побудові нових соціальних структур та інше.

Слід зауважити, що саме у сучасному «мережевому суспільстві», яке утворилось за допомогою комп'ютерних технологій, Інтернету виникають найбільш сприятливі умови для встановлення різноманітних соціальних зв'язків і відносин, які можуть бути задіяні і використані у моменти самоорганізації суспільства у періоди соціального хаосу і нестабільності. Мережеве суспільство має певну низьку переваг, порівнюючи його з традиційним, і перш за все, ці переваги торкаються питання свободи особистості, її самореалізації, самоорганізації. Тому можна казати про виникнення певного типу соціального суб'єкта у мережевому суспільстві, а саме «суб'єкта-атрактора», тобто особистості, яка формує певні локальні центри та має локальний вплив на інших. Формування такої особистості

\footnotetext{
${ }^{1}$ Донникова, И. (2011). Культурогенная сущность сочиальной саморганизачии. Одесса: Печатный дом, 280.

2 Ершова-Бабенко, И. В. (2015). Психосинергетика. Херсон: Гринь Д.С., 37-41.

${ }_{3}^{3}$ Ершова-Бабенко, И. В. (2019). Гипертеория "brain-psyche-mind/conciousness" постнеклассическое общее решение проблемы и методология исследования психомерности. Norwegian Journal of Development of the International Science, 29 (3), 45-50; Ершова-Бабенко, И. В. (2020). Психосинергетика: методологический статус, теория и практика. юбилейный сборник научных трудов профессора И. В. Ершовой-Бабенко. Одесса: Фенікс, 256.
} 
залежить, однак не тільки від зовнішних впливів, тобто від умов, які створені у мережевому суспільстві, але й внутрішних чинників, психічної складової, яка в умовах хаосу і нестабільності набуває нового сенсу і значення.

3 іншого боку, активність людини і ії̈ здатність до самоорганізації і саморозвитку розглядається сьогодні у сучасному екологічному підходу у філософії. Завдяки екології людини як нового напрямку сучасної філософії піднімаються такі питання як екологія психіки людини, ії взаємовідносини 3 оточуючим середовищем, іiі соціальна поведінка і дії у суспільстві та інше. Основою для цього філософського напрямку були ідеї німецького вченого, зоолога ХХст. Я. фон Ікскюля, що були виражені у його концепті «Umwelt» ${ }^{1}$. Цей концепт, який виник на підставі його спостережень за тваринами, використовувався ним також для опису людського існування, яке $є$ залежним від найближчого оточуючого людину середовища. Тобто людина здатна побудувати власний Umwelt, виходячи з особливостей своєї психічної організації і соціального оточення. У психосинергетиці поняття Umwelt можно порівняти з поняттям «психомірності» та «психомірної системи/середовища», оскільки ці концепти описують існування людини в якості складної цілісності, що поєднує тілесні, емоційні, енергетичні, когнитивні і соціальні аспекти людського існування. Тому як поняття Umwelt, так само і концепт «психомірності» ставлять питання про взаємовідносини людини і соціального середовища як проблеми екологічні і соціальні.

Крім того, до «екологічної філософії» відносять теорію «екології дії» Е. Морена ${ }^{2}$, концепцію «антікрихкості» Н. Талеба ${ }^{3}$, теорію енактивізму та комунікації О. Князевої ті інші. Всі ці філософські ідеї орієнтовані на пошук нових засад для формування нових взаємовідносин людини, природи і соціуму, які сприятимуть як збереженню природного світу, так і встановленню нових відносин між людиною i соціальним середовищем, які мають гармонічний, екологічний вимір. Тому психосинергетика сьогодні не є лише складовою частиною психологічного знання, але й вона має широке теоретичне і практичне значення. Психосинергетичні стратегії у вигляді практичних розробок, методик, тощо, які використовуються для подолання хаосу на особистісному рівні мають у сучасному суспільстві широкі перспективи і важливе значення.

Оскільки сьогодні як ніколи раніше зростає необхідність «психологічного» оснащення особистості, яке полягає у вміннях і навичках, що сприяють самозбереженню власного «психомірного середовища» (Umwelt), вміння оріснтуватися в умовах невизначеності, непередбачуваності i транзитивності світу. Таким чином, психосинергетичні стратегії органічно входять у сучасний соціальний дискурс (теорію соціальної самоорганізації), оскільки відкривають нові можливості і перспективи для розвитку самоорганізації особистості як складного психомірного середовища/системи, що самоорганізується в умовах соціального хаосу і соціальних трансформацій.

\section{Висновки}

Здійснивши аналіз філософської і соціально-філософської літератури, було розкрито нове значення психосинергетики у соціальному знанні, яке грунтується на твердженні, що психічна діяльність особистості, яка $\epsilon$ складною психомірною системою/середовищем утворює разом з суспільством, яке $є$ також психомірною системою «нелінійну складну цілісність» (І.В. ЄршоваБабенко). Ця модель «нелінійної цілісності» представлена у психосинергетиці як нова модель «ціле-вцілому», або «ціле в цілому». В психосинергетиці базовим є постнекласичне визначення психіки: психіка $\epsilon$ складною гіперсистемою з фазовою структурою і міжфазовими переходами. Завдяки цьому взаємовідносини і взаємодія між особистістю і суспільством, які особливо важливими стають у періоди соціального хаосу, набувають нового психологічного виміру. Тому доречним виглядає запровадження в роботі нового поняття «хаотизація психомірності соціуму», яке показує, що особистість як складна психомірна система, що самоорганізується, здатна долати кризові моменти у суспільстві шляхом власної самоорганізації. Отже, процеси соціальної самоорганізації у суспільстві як складній нелінійній соціальній системі спираються на особистість і її власну здатність до самоорганізації.

\footnotetext{
${ }^{1}$ Князева, Е. Н. (2015). Понятие “Umwelt” Якоба фон Икскюля и его значимость для современной эпистемологии. Вопросы философии $<$ http://vphil.ru/index.php?option=com_content\&task=view\&id=1155\&Itemid=52> (2021, серпень, 30).

${ }^{2}$ Морен, Э. (2013). Образование в будущем: Семь неотложных задач. Синергетика. Антология. Санкт-Петербург: Центр гуманитарных инициатив, 247-322.

3 Талеб, Н. Н. (2017). Антихрупкость. Как извлечь выгоду из хаоса. Москва: КоЛибри, Азбука-Аттикус.

${ }^{4}$ Князева, Е. Н. (2014). Энактивизм: новая форма конструктивизма в эпистемологии. Санкт-Петербург: Центр гуманитарных инициатив, 352.
} 


\section{References:}

1. Astafeva, O. N., Dobronravova, I. S. (2009). Sotsiokulturnaya sinergetika v Rossii i Ukraine: predmetnaya oblast, istoriya i perspektivy [Sociocultural synergetics in Russia and Ukraine: subject area, history and prospects]. Postneklassika: filosofiya, nauka, kultura [Post-nonclassics: philosophy, science, culture]. St. Petersburg: Mir. [in Russian].

2. Bachinin, V. A. (2003). Sotsiologiya [Sociology]. Kharkov: Konsum. [in Russian].

3. Bevzenko, L. D. (2002). Sotsialnaya samoorganizatsiya Sinergeticheskaya paradigma: vozmozhnosti sotsialnykh interpretatsii [Social Self-Organization Synergetic Paradigm: Possibilities of Social Interpretations]. Kyiv: Institut sotsiologii NAN Ukrainy. [in Russian].

4. Gritsanov, A. (2007). Khaosmos. Postmodernizm [Chaosmos. Postmodernism]. Noveishii filosofskii slovar [The latest philosophical dictionary]. Minsk: Sovremennyi literator. [in Russian].

5. Dobronravova, I. S. (1990). Sinergetika: stanovlenie nelineinogo myshleniya [Synergetics: the formation of non-linear thinking]. Kyiv: Libid. [in Russian].

6. Donnikova, I. (2011). Kulturogennaya sushchnost sotsialnoi samorganizatsii [Cultural essence of social self-organization]. Odessa: Pechatnyi dom. [in Russian].

7. Ershova-Babenko, I. V. (1992). Metodologiya issledovaniya psikhiki kak sinergeticheskogo obekta [Methodology for the study of the psyche as a synergistic object]. Odessa: Odekom. [in Russian].

8. Ershova-Babenko, I. V. (2015). Psikhosinergetika [Psychosynergetics]. Kherson: Grin, D.S.”, 488, [in Russian].

9. Ershova-Babenko, I. V. (2019). Giperteoriya "brain-psyche-mind/conciousness" postneklassicheskoe obshchee reshenie problemy i metodologiya issledovaniya psikhomernosti [Hypertheory "brown-psyche-mind / conciusness" post-nonclassical general solution to the problem and the methodology of the study of psycho-dimensionality]. Norwegian Journal of Development of the International Science, 29 (3), 45-50, [in Russian].

10. Ershova-Babenko, I. V. (2020). Psikhosinergetika: metodologicheskii status, teoriya i praktika. yubilejnyj sbornik nauchnykh trudov professora I. V. Ershovoj-Babenko [Psychosynergetics: methodological status, theory and practice. jubilee collection of scientific works of Professor I. V. Ershova-Babenko]. Odessa: Feniks. [in Russian].

11. Ershova-Babenko, I. V., Seliverstova, G. (2021). «Zvyazok chasiv» kriz prizmu ponyattya «khaos» $\mathrm{v}$ davnokitaiskii mifologii i sotsialnij filosofii XXI st ["Connection of times" through the prism of the concept of "chaos" in ancient Chinese mythology and social philosophy of the XXI century]. Norwegian Journal of development of the International Science, 64, 53-58. [in Ukrainian].

12. Knyazeva, E. N., Kurdyumov, S. P. (2002). Osnovaniya sinergetiki. Rezhimy s obostreniem, samoorganizatsiya, tempomiry [Foundations of synergetics. Exacerbation modes, self-organization, tempomir]. St. Petersburg: Aleteiya. [in Russian].

13. Knyazeva, E. N. (2014). Enaktivizm: novaya forma konstruktivizma v epistemologii [Enactivism: A New Form of Constructivism in Epistemology]. St. Petersburg: Tsentr gumanitarnykh initsiativ. [in Russian].

14. Knyazeva, E. N. (2015). Ponyatie "Umwelt" Yakoba fon Ikskyulya i ego znachimost' dlya sovremennoi epistemologii [The concept of "Umwelt" by Jacob von Uexkyl and its significance for modern epistemology]. Voprosy filosofii [Philosophy questions] <http://vphil.ru/index.php?option=com_content\&task=view\&id=1155\&Itemid=52>. [in Russian].

15. Laslo, E. (1995). Vek bifurkatsii: postizhenie izmenyayushchegosya mira [The Age of Bifurcation: Comprehension of the Changing World]. Put [Way], 1, 3-129, [in Russian].

16. Lebedev, A. V. (1989). Fragmenty rannikh grecheskikh filosofov [Fragments of early Greek philosophers]. Mjscow: Nauka. [in Russian].

17. Tokarev, S. A. (ed.) (1980). Khaos. Mify narodov mira [Chaos. Myths of the peoples of the world]. Entsiklopediya [Encyclopedia]. Moscow: Sovetskaya Entsiklopediya, 2, 579-581. [in Russian].

18. Moren, E. (2013). Obrazovanie v budushchem: Sem' neotlozhnykh zadach [Education for the Future: Seven Imperatives]. Sinergetika. Antologiya [Synergetics. Anthology]. St. Petersburg: Tsentr gumanitarnykh initsiativ, 247-322. [in Russian].

19. Nikolis, G., Prigozhin, I. (1979). Samoorganizatsiya v neravnovesnykh sistemakh: ot dissipativnykh struktur $k$ uporyadochennosti cherez fluktuatsii [Self-organization in nonequilibrium systems: from dissipative structures to ordering through fluctuations]. Moscow: Mir. [in Russian].

20. Omelchenko, N. (2006). Fenomen sotsialnogo khaosu: filosofskii analiz [The phenomenon of social chaos: a philosophical analysis]: avtoreferat na zdobuttya naukovogo stupenya kandidata filosofskikh nauk [abstract for the degree of candidate of philosophical sciences]. Zaporizhzhya: ZNU. [in Russian].

21. Rozhanskii, I. D. (1972). Anaksagor. U istokov antichnoi nauki [Anaxagoras. At the origins of ancient science]. Moscow: Mysl. [in Russian].

22. Seliverstova, G. S. (2021). Khaos yak predmet sotsialnoyi filosofiyi [Chaos as a subject of social philosophy]: dysertatsiya na zdobuttya naukovoho stupenya kandydata filosofskykh nauk [the dissertation on competition of a scientific degree of the candidate of philosophical sciences]. Odesa: PPNU im.K.D. Ushins'kogo, 185, [in Ukrainian]. 
23. Taleb, N. N. (2017). Antikhrupkost. Kak izvlech vygodu iz khaosa [Antifragility. How to capitalize on the chaos]. Moscow: KoLibri, Azbuka-Attikus. [in Russian].

24. Khaken, G. (1980). Sinergetika [Synergetics]. Moscow: Mir. [in Russian].

25. Lorenz, E. N. (1972). Predictability: does the flap of a butterfly's wings in Brazil set off a tornado in Texas? 139th Annual Meeting of the American Association for the Advancement of Science (29 Dec 1972), in Essence of Chaos. Appendix 1, 181, [in English].

26. Maldenbrot, B. (1982). The Fractal Geometry of Nature. San Francisco: Freeman W.H. and Co. [in English]. 